\title{
Initial Study on Phytoextraction for Recovery of Metals from Sorted and Aged Waste-to-Energy Bottom Ash
}

\author{
Karin Karlfeldt Fedje ${ }^{1,2, * \mathbb{C}}$, Viktoria Edvardsson ${ }^{2}$ and David Dalek ${ }^{2}$ \\ 1 Department of Architecture and Civil Engineering, Division of Water Environment Technology, \\ Chalmers University of Technology, SE-412 96 Gothenburg, Sweden \\ 2 Recovery and Management, Renova AB, Box 156, SE-401 22 Gothenburg, Sweden; \\ viktoria.edvardsson@renova.se (V.E.); david.dalek@renova.se (D.D.) \\ * Correspondence: karin.karlfeldt@chalmers.se
}

Citation: Karlfeldt Fedje, K.; Edvardsson, V.; Dalek, D. Initial Study on Phytoextraction for Recovery of Metals from Sorted and Aged Waste-to-Energy Bottom Ash. Soil Syst. 2021, 5, 53. https://doi.org/ 10.3390 /soilsystems 5030053

Academic Editors: Matteo Spagnuolo, Paola Adamo and Giovanni Garau

Received: 17 August 2021

Accepted: 26 August 2021

Published: 31 August 2021

Publisher's Note: MDPI stays neutral with regard to jurisdictional claims in published maps and institutional affiliations.

Copyright: (c) 2021 by the authors. Licensee MDPI, Basel, Switzerland. This article is an open access article distributed under the terms and conditions of the Creative Commons Attribution (CC BY) license (https:/ / creativecommons.org/licenses/by/ $4.0 /)$.

\begin{abstract}
Sorted and aged bottom ash from Waste-to-Energy plants, i.e., MIBA (the Mineral fraction of Incinerator Bottom Ash) are potential source of metals that could be utilized to meet the increased demand from society. In this work, sunflowers (Helianthus annuus) and rapeseed (Brassica napus) were cultivated in conventional MIBA to evaluate the possibility for phytoextraction, mainly of Zn, during the period of one cultivation season in the Nordic climate. The results show that metal extraction from MIBA using rapeseed and sunflowers is workable but that neither of the used plants is optimal, mainly due to the inhibited root development and low water- and nutrient-holding capacities of MIBA. The addition of fertilizer is also important for growth. There was a simultaneous accumulation of numerous metals in both plant types, and the highest metal content was generally found in the roots. Calculations indicated that the ash from rapeseed root incineration contained about $2 \% \mathrm{Zn}$, and the contents of $\mathrm{Co}, \mathrm{Cu}$, and $\mathrm{Pb}$ were comparable to those in workable ores. This initial study shows that cultivation in and phytoextraction on MIBA is possible, and that the potential for increased metal extraction is high.
\end{abstract}

Keywords: WtE bottom ash; phytoextraction; zinc recovery; rapeseed; sunflower; MIBA

\section{Introduction}

The demand for metals is increasing in our society. The importance of a secure metal supply has been acknowledged by the European Commission, which has recommended the utilization of secondary raw materials as a way to achieve this [1]. When waste is incinerated using the most common technique, Waste-to-Energy (WtE) mass burn combustion, about $20 \%$ of the mass becomes what is known as bottom ash. In Sweden alone, almost 1 million tons of this type of bottom ash is produced annually; in the EU, Norway, and Switzerland, the corresponding amount is approximately $18 \mathrm{Mt} /$ year [2,3]. These ashes contain significant amounts of metals, and the most common treatment method for bottom ash is mechanical separation, where pieces of metal are recovered and combined with natural weathering, i.e., carbonation. Ash having had this treatment is referred to as MIBA, the Mineral fraction of Incinerator Bottom Ash, to distinguish it from untreated bottom ash [3]. This treatment does not only recycle solid metals but also stabilizes the material $[4,5]$ and opens it up for utilization. In some countries, e.g., Denmark and the Netherlands, MIBA is used for conventional road construction, whereas in others, including Sweden, Norway, and Switzerland, it is landfilled or used within landfills [3]. The variance in management approaches is a result of the different guidelines and legislation used in different countries [3]. Current guidelines and legislation are strongly correlated to the presence and potential leaching of metals, as even after mechanical metal recovery, a significant amount of metal remains in the MIBA, either bound in chemical compounds or as small pieces (typically $<1 \mathrm{~mm}$ ); see, e.g., [6,7]. If more metals were to be removed, the 
potential fields of application for MIBA would increase significantly, and most importantly, these resources could be utilized instead of virgin metals needing to be mined.

Recovery of the metals remaining in MIBA cannot be carried out using physical separation, but thermal or hydrometallurgical processes could potentially be used. The content of, e.g., $\mathrm{Cu}$ in MIBA is comparable to workable ores, but as the MIBA matrix is different from a rock, the amounts are still too low to be of interest to the energy-intensive metal refining industry [8]. Additionally, the presence of unwanted elements such as $\mathrm{Cl}$ and As may harm the recovery process [8]. Instead, MIBA must be treated to generate concentrates with higher contents of interesting metals and lower amounts of unwanted elements. Hydrometallurgical processes, i.e., leaching combined with, e.g., chemical precipitation, could be a way to get such material. However, the main challenge is the huge amounts of leaching media needed for MIBA treatment. Pure water is not efficient enough to leach metals, and assuming a liquid-to-solid ratio of 4 , almost 4 million $\mathrm{m}^{3}$ leaching agents would be required for Sweden alone. Even if part of the leachate was re-circulated, the large amounts of liquid would still be problematic. In this perspective, phytoextraction is an interesting alternative for metal recovery from MIBA, as it offers a way to extract and concentrate the metals of interest. Phytoextraction uses specific plants, so-called hyperaccumulators, that cannot only survive in contaminated areas but can also extract the contaminants into their tissues. Once harvested, these plants can be incinerated, and metals can be recovered from the resulting ash. Successful laboratory-scaled Ni recovery experiments which combine phytoextraction with separate incineration of the Ni-enriched plants have been reported [9]. However, separate incineration is usually not an alternative if used on a full scale. Instead, incineration of the enriched plants in conventional full-scale WtE plants is favorable, and the metals enriched in plants would likely be found in the fly ash [10]. This is positive, as the recovery of metals from WtE fly ash has been in focus for many years. Zn especially is of high interest, and several successful initiatives for $\mathrm{Zn}$ recovery from ash are under development or present as full-scale processes [11-13]. This makes the production of a $\mathrm{Zn}$-rich fuel generated from the growth of hyperaccumulators in MIBA especially interesting, as this would transfer the $\mathrm{Zn}$ from the challenging MIBA matrix into a material from which $\mathrm{Zn}$ can be recovered efficiently. Besides, in the future, methods for the recovery of other valuable metals in fly ash are likely to be developed as well.

Phytoextraction is used for treating contaminated soils all over the world; however, a drawback for the Nordic countries is that many of the known Zn hyperaccumulators, e.g., water hyacinth (Eichhornia crassipes), do not grow naturally in their climate [14]. Further, several of the potential plants have limited biomass, including alpine pennycress (Thlaspi caerulescens) [15]. However, sunflowers (Helianthus annuus), rapeseed (Brassica napus), corn (Zea mays), and haricot verts (Phaseolus vulgaris), as well as larger plants, such as salix trees, have also been shown to accumulate Zn [15-22]. Generally, experiments carried out so far have used contaminated soils with few contaminants, and there is a lack of studies of scientifically controlled cultivation on ash containing several potential pollutants. Most earlier studies have used coal ash [23,24]; however, there is one published study where manually sorted and washed bottom ash from WtE incineration was used [25]. The results of this study showed that $\mathrm{Ni}$ and $\mathrm{Zn}$ were extracted by Alyssum (serpyllifolium) and a succulent (S. plumbizincicola), respectively, although the biomass production was low. To the best of the authors' knowledge, no study on phytoextraction from conventional MIBA has been scientifically considered.

This project aimed to study phytoextraction, mainly of Zn, from conventional MIBA during the period of one cultivation season in the Nordic climate. The specific goals were to evaluate the survival of the plants in MIBA and to evaluate the potential to generate Zn-enriched fuel, which is to be used for metal recovery. Additionally, the simultaneous decrease in the metal content in the remaining MIBA was measured. 


\section{Material and method}

\subsection{Material}

The MIBA used in this work originated from a full-scale WtE-incineration plant in southwestern Sweden. The waste, mainly municipal and industrial waste, was incinerated in four grate-fired furnaces with steam boilers that produced electricity and district heating. Bottom ash was collected from all lines, mixed, and stored in large piles that were naturally weathered, i.e., not sheltered against wind or water, for at least 6 months. After 1-3 months in storage, metal pieces $(>\sim 2 \mathrm{~mm})$ were mechanically removed using mobile sorting equipment with magnets and eddy current magnets. Sub-samples from the MIBA were collected and mixed to form one sample of about $600 \mathrm{~kg}$, which was used for the cultivation tests.

For the control cultivation, where sunflowers and rapeseed were cultivated under normal circumstances, a commercial "lean planting soil" generated from the biological treatment of garden waste was used (Table 1) (Reference soil) [26]. To promote plant growth, and to study the effect of fertilizer on this growth, the reference cultivation boxes and half of the cultivation boxes containing MIBA were fertilized with YaraMila Promagna 11-5-18. This fertilizer is specially developed for plants with a high need for $\mathrm{N}$, which is a shortage in MIBA [27].

\subsection{Cultivation Experiments}

Suitable plant types were chosen based on a review of the literature, with the prerequisites that the selected plants should be able to: grow on open land in a Nordic climate, obtain significant relative biomass within one cultivation season, and have a proven affinity for $\mathrm{Zn}$. Further, the plants should preferably have a dense structure, to ensure good incineration properties in recovery processes. Sunflowers (Helianthus annuus) are known to be suitable for phytoremediation of $\mathrm{Zn}$, but other cruciferous plants, such as rapeseed (Brassica napus), have also been shown to be appropriate [17,18,25,28,29]. Additionally, as rapeseed and sunflowers both have variations of taproots, these plants were chosen for the cultivation experiments.

The experiments were performed using six cultivation boxes of about $1 \mathrm{~m}^{2}$ each. The boxes were prepared in several layers, starting with a plastic covering on the inside, to prevent uncontrolled leaching. Thereafter, an approximately $15-\mathrm{cm}$ thick layer of leca (Light Expanded Clay Aggregate) spheres was placed in the bottom, followed by a ground cloth. Finally, about $30 \mathrm{~cm}$ of MIBA or reference soil (control cultivation) was placed on top of the ground cloth in each box. In total, 6 boxes were prepared for the cultivation experiments, 4 cultivation experiments in MIBA and 2 control cultivation experiments in reference soil:

- Sunflowers in MIBA without fertilizer (SwoF)

- Sunflowers in MIBA with fertilizer (SF)

- Sunflowers in reference soil with fertilizer (Sref)

- $\quad$ Rapeseed in MIBA without fertilizer (RwoF)

- $\quad$ Rapeseed in MIBA with fertilizer (RF)

- $\quad$ Rapeseed in reference soil with fertilizer (Rref)

Seeds of both sunflowers and rapeseed were supplied by the agriculture cooperative Lantmännen. The sunflowers were pre-cultivated in reference soil in a greenhouse and were about $20 \mathrm{~cm}$ high when planted in the boxes, while the rapeseed plants were grown directly in the boxes. To improve the growing conditions, small holes, about $2-4$ centimeters deep, were made in the MIBA boxes. The holes were filled with reference soil and the plants and seeds were grown inside the holes. Eight holes, i.e., eight plants, were made in each sunflower box, while twelve holes were used for the rapeseed. Several rapeseed plants were planted in each hole. Rapeseed was also planted directly in MIBA. Fertilizer was added one week after planting, in amounts according to the recommendation from the producer. All boxes were placed in similar sun and wind conditions. Watering using ordinary tap water, management, and growth checks (ocular and height measurement) 
were carried out regularly during the growing season (end of April to the middle of September). Some excess water was collected in the bottom of the boxes, where it could not reach the roots. This water was not returned to the plants. Approximately 6 weeks after planting, the rapeseed plants were thinned out in some of the planting groups. This was done to study whether or not having a large number of rapeseed plants within a small area would harm their growth.

Table 1. Contents in original reference soil, MIBA and the fertilizer used. Additionally, leaching (L/S 10) from MIBA according to SS-EN-12357-3 is shown. All amounts are provided in mg/kg DS except pH, TOC, ANC, EC, and bulk density.

\begin{tabular}{|c|c|c|c|c|c|c|c|}
\hline \multirow[b]{2}{*}{ Element } & \multirow{2}{*}{$\begin{array}{l}\text { Reference Soil } \\
\text { Total Amounts }\end{array}$} & \multirow[b]{2}{*}{ SD } & \multirow[b]{2}{*}{ Total Amounts } & \multicolumn{2}{|c|}{ MIBA } & \multirow[b]{2}{*}{ SD } & \multirow{2}{*}{$\begin{array}{c}\text { Fertilizer } \\
\text { Total Amounts }\end{array}$} \\
\hline & & & & SD & Leaching (L/S 10) & & \\
\hline $\mathrm{Al}$ & 11,000 & -1 & 59,000 & 7700 & $\mathrm{na}^{2}$ & - & na \\
\hline As & 1.8 & 0.5 & 26 & 7 & 0.05 & 0.02 & na \\
\hline $\mathrm{B}$ & 8.5 & - & 200 & 30 & na & - & 500 \\
\hline $\mathrm{Ba}$ & 92 & 4.1 & 1700 & 260 & 1.1 & 0.05 & na \\
\hline $\mathrm{Be}$ & 0.6 & - & 1.4 & 0.20 & na & - & na \\
\hline $\mathrm{Ca}$ & 6317 & 878 & 130,000 & 1000 & na & - & na \\
\hline $\mathrm{Cd}$ & 0.13 & 0.04 & 2.5 & 0.6 & 0.003 & 0.001 & $<55^{3}$ \\
\hline Co & 7.3 & 0.5 & 39 & 24 & na & - & na \\
\hline $\mathrm{Cr}$ & 14 & 1.1 & 440 & 220 & 0.26 & 0.15 & na \\
\hline $\mathrm{Cu}$ & 27 & 4.3 & 3400 & 1500 & 3.2 & 0.15 & 300 \\
\hline $\mathrm{Fe}$ & 16,900 & - & 53,000 & 11,000 & na & - & 800 \\
\hline $\mathrm{Hg}$ & 0.032 & 0.004 & 0.025 & 0.002 & $<0.001$ & - & na \\
\hline K & 5087 & 147 & 11,000 & 1600 & na & - & 176,000 \\
\hline $\mathrm{Mg}$ & 4490 & 70 & 13,000 & 840 & na & - & 16,000 \\
\hline $\mathrm{Mn}$ & 330 & - & 1100 & 160 & na & - & 2500 \\
\hline Mo & 2.7 & 2.0 & 27 & 22 & 1.2 & 0.24 & 20 \\
\hline $\mathrm{N}$ & 2250 & 150 & na & na & na & - & 110,000 \\
\hline $\mathrm{Na}$ & 558 & - & 24,000 & 2100 & na & - & na \\
\hline $\mathrm{Ni}$ & 10 & 2.5 & 200 & 100 & 0.09 & 0.03 & na \\
\hline $\mathrm{P}$ & 919 & 269 & 4100 & 360 & na & - & 46,000 \\
\hline $\mathrm{Pb}$ & 15 & 1.9 & 1600 & 1300 & 0.23 & 0.20 & na \\
\hline$S$ & 671 & 225 & 8900 & 210 & na & - & 100,000 \\
\hline $\mathrm{Sb}$ & 0.9 & 0.4 & 80 & 23 & 0.34 & 0.03 & na \\
\hline Se & $<5.0$ & - & na & - & 0.02 & 0.01 & na \\
\hline $\mathrm{Si}$ & na & - & 160,000 & 25,000 & na & - & na \\
\hline Sn & 1.5 & - & 200 & 110 & na & - & na \\
\hline $\mathrm{Sr}$ & 27 & - & 390 & - & na & - & na \\
\hline $\mathrm{Ti}$ & na & - & 8700 & 720 & na & - & na \\
\hline $\mathrm{V}$ & 26 & 1.5 & 48 & 4.4 & na & - & na \\
\hline $\mathrm{Zn}$ & 103 & 20 & 5000 & 1100 & 1.6 & 1.4 & na \\
\hline $\mathrm{Cl}^{-}$ & na & - & na & - & 3200 & 360 & na \\
\hline $\mathrm{F}^{-}$ & na & - & na & - & 2.7 & 0.55 & na \\
\hline $\mathrm{SO}_{4}{ }^{2-}$ & na & - & na & - & 10,700 & 3900 & na \\
\hline DOC & na & - & na & - & 220 & 64 & na \\
\hline $\mathrm{pH}$ & 6.8 & 0.05 & na & - & 9.4 & 1.0 & na \\
\hline TOC [\%] & 6.8 & 1.4 & 1.2 & 0.1 & na & - & na \\
\hline Humus content $[\%]$ & 17.1 & 0.6 & na & - & na & - & na \\
\hline $\mathrm{ANC}\left[\mathrm{mol} \mathrm{H}{ }^{+} / \mathrm{kg}\right.$ DS $]$ & na & - & 2.3 & 0.2 & na & - & na \\
\hline $\mathrm{EC}_{\mathrm{sw}}{ }^{4}[\mathrm{mS} / \mathrm{m}]$ & na & - & na & - & 820 & 38 & na \\
\hline Bulk density $\left[\mathrm{kg} / \mathrm{m}^{3}\right]$ & 700 & $<1$ & $1080^{5}$ & - & na & - & na \\
\hline
\end{tabular}

${ }^{1}$ Not possible to calculate due to a single sample or parameter not analyzed; ${ }^{2}$ Not analyzed; ${ }^{3}$ Re-calculated from a maximum of $12 \mathrm{mg} \mathrm{Cd} / \mathrm{kg} \mathrm{P} ;{ }^{4} \mathrm{~L} / \mathrm{S} 2 ;{ }^{5}$ Re-calculated from a natural moisture content of $10 \%$.

After 20 weeks, the plants were gently harvested manually using small spades. The plants, and any reference soil or MIBA on or close to their roots, were collected and dried at room temperature for 1 week. Due to the low growth rate, small sub-samples were collected from several cultivation spots in each box, then mixed into one MIBA sample per box. For consistency, only one sample from each reference box was collected according to 
the same methodology. The dried plants were separated into below-ground biomass, i.e., roots and above-ground biomass, before further analysis. The only exception was RwoF, as the biomass from this box was too small to allow separation into different plant fractions.

\subsection{Chemical Analyses}

Total element concentrations in the original MIBA and the solid residues after cultivation were analyzed at accredited laboratories (Eurofins, Luxembourg, and Synlab, Munich, Germany) by melting with $\mathrm{LiBO}_{2}$ followed by dissolution in $\mathrm{HNO}_{3}$ according to ASTM D3682: 2013 and ASTM D4503: 2008, or with $\mathrm{HNO}_{3} / \mathrm{HCl} / \mathrm{HF}$ according to SS-EN 13656: 2003. Final analysis of the solutions was performed using ICP-SFMS (Inductively Coupled Plasma-Sector Field Mass Spectrometry) according to SS-EN ISO 17294-2: 2016 and EPA method 200.8: 1994. A total content analysis of the elements in the soil before and after cultivation was carried out at an accredited laboratory (Eurofins, Luxembourg) by dissolution in aqua regia according to SS-ISO 11466, followed by analysis with ICP-SFMS (SS-EN ISO 17294-1, 2 (mod) or EPA method 200.8 (mod)) or ICP- AES (Inductively coupled plasma atomic emission spectroscopy) (SS-EN ISO 11885 (mod) and EPA method 200.7 (mod)). The contents in the original MIBA and reference soil were analyzed in triplicates, while the residues after harvest, due to limited sample volume, were analyzed as singlicates.

The total organic carbon (TOC) and acid-neutralizing capacity (ANC) of the MIBA were analyzed at an accredited laboratory (Eurofins, Luxembourg) in duplicate, using SS-EN 13137: 2001 and EN 14429: 2015, respectively. The particle size distribution in MIBA was carried out as singlicate ( $30 \mathrm{~g}$ ) at the Chalmers University of Technology using EN 933-1. The particle size distribution and humus content in soil were analyzed in triplicates using SS ISO-11277 (2009), while TOC was analyzed using SS-EN 15936: 2012 metodappl. A/SS-EN 13137: $2001 \mathrm{~m}$ and pH using DIN ISO 10390: 2005-12, all in triplicates and at accredited laboratories (Eurofins, Luxembourg). The bulk density of the soil was analyzed in triplicate (internal method at the accredited laboratory Eurofins, Luxembourg), while the corresponding value for MIBA was calculated from data in [30,31].

A 5-step sequential extraction scheme based on [32] was performed by an accredited laboratory (Synlab, Munich, Germany) on the original MIBA (single sample) to study the potential mobility and operational binding forms of selected elements [33]. The method uses $1 \mathrm{M} \mathrm{NaOAc}, \mathrm{pH} 5$, to extract easily adsorbed and exchangeable metals and carbonates, followed by $\mathrm{Na}_{4} \mathrm{P}_{2} \mathrm{O}_{7}$ to extract metals weakly bound to organic matter, $0.25 \mathrm{M}$ $\mathrm{NH}_{2} \mathrm{OH} \cdot \mathrm{HCl}$ in $0.1 \mathrm{M} \mathrm{HCl}$ in $60{ }^{\circ} \mathrm{C}$ to extract metals bound to amorphic iron and manganese oxides, $1.0 \mathrm{M} \mathrm{NH}_{2} \mathrm{OH} \cdot \mathrm{HCl}$ in $25 \% \mathrm{CH}_{3} \mathrm{COOH}$ in $90^{\circ} \mathrm{C}$ to extract metals bound to crystalline iron oxides, and finally $\mathrm{KClO}_{3}$ in $12 \mathrm{M} \mathrm{HCl} 4 \mathrm{M} \mathrm{HNO}_{3}$ in $90^{\circ} \mathrm{C}$ to extract metals bound to the stable organic forms and sulfides. The leachates were analyzed according to SS-EN ISO 17294-1,2 (mod)/EPA-method 200.8 (mod) and SS 028150-2.

To evaluate potential leaching, SS-EN-12457-3 was performed on representative original MIBA samples. The test was carried out in duplicate. The $\mathrm{pH}$ of the leachates was measured according to SS-EN ISO 10523: 2012. The electrical conductivity (EC) of the leachates was measured according to SS-EN 27888-1 at a liquid-to-solid (L/S) ratio of 2. All analyses were conducted at accredited laboratories (Eurofins, Luxembourg, and Synlab, Munich, Germany).

The elemental contents of the harvested plants (above- and below-ground biomass) were analyzed after microwave digestion with $\mathrm{HNO}_{3} / \mathrm{H}_{2} \mathrm{O}_{2}$ using ICP-SFMS according to SS-EN ISO 17294-2: 2016 and EPA method 200.8: 1994. The analyses were done at an accredited laboratory (Synlab, Munich, Germany) in duplicate.

\section{Result and Discussion}

\subsection{Characterisation of Original MIBA}

Biomass ashes are known to act as a fertilizer and promote the growth of trees when spread in woods or used in agricultural processes [34,35]. The Swedish Forest Agency has issued recommendations on the total content of different elements in biomass ashes to be 
reintroduced to a forest [36]. A comparison between those values and the contents of the MIBA samples used in this study showed that of the macronutrients $(\mathrm{Ca}, \mathrm{K}, \mathrm{P}, \mathrm{Mg})$, $\mathrm{Ca}$ and $\mathrm{Mg}$ were present in sufficient concentrations, whereas the $\mathrm{K}$ and $\mathrm{P}$ contents were too low (Table 1). This shows that there is potential for plants to grow in MIBA and that growth could be promoted by adding NPK fertilizer. However, the amounts of the potentially toxic metals $\mathrm{Cr}, \mathrm{Cu}, \mathrm{Ni}$, and $\mathrm{Pb}$ all exceeded the recommended levels, and it is well known that this can inhibit growth, especially of the roots; see, e.g., [37] and references therein. On the other hand, their mobility in water is low (Table 1) and sequential extraction has shown that of these elements, $\mathrm{Pb}$ was the only one with a high proportion present in exchangeable and adsorbed forms (Figure 1). In addition to $\mathrm{Pb}, \mathrm{Zn}, \mathrm{Cd}$, and $\mathrm{Ca}$ are also highly mobile and were present in more than $50 \%$ of the exchangeable fraction. Chromium and $\mathrm{Ni}$ were mainly present in stable forms (steps 4 and 5), and are unlikely to be as available for phytoextraction. For most elements, the presence in step 2 (labile organic forms) was $<10 \%$, which was expected, as the TOC in MIBA is low (Table 1). The predicted mobility of $\mathrm{Cu}$ is low, and $>70 \%$ was present in the sulfide fraction (step 5). The consistency of the results from the total elemental analyses for the other elements was acceptable between the methods. The mobility of anions, such as chloride and sulfate, as well as $\mathrm{EC}_{\mathrm{sw}}$, were noteworthy (Table 1), as high salinity is known to affect plant growth negatively [38].

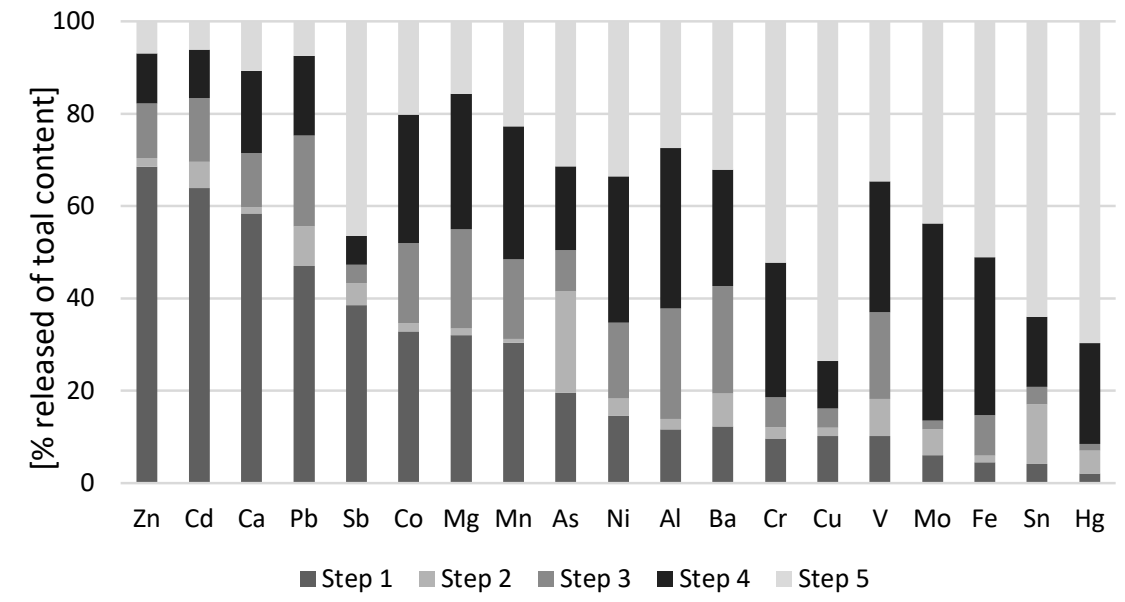

Figure 1. Sequential extraction distribution for original MIBA. Step 1: easily adsorbed and exchangeable metals and carbonates, Step 2: metals weakly bound to organic matter, Step 3: metals bound to amorphic iron and manganese oxides, Step 4: metals bound to crystalline iron oxides, and Step 5: metals bound to stable organic forms and sulfides.

\subsection{Plant Growth and Biomass}

The plant height growth was initially similar for all sunflower plants (Figure 2a). However, after a few weeks, the rate decreased in the MIBA boxes, and after a few more weeks, the MIBA plants started to lose their leaves and dried out. The addition of fertilizer had only a minor effect on growth, which could have been due to the presence of potentially toxic elements like $\mathrm{Cu}, \mathrm{Zn}$, and $\mathrm{Cl}$ that may inhibit nutrient uptake and affect plant growth negatively [37-39]. Additionally, sunflower roots are likely to be too weak to efficiently penetrate the compact MIBA and therefore don't absorb enough water and nutrients (Table 1).

Rapeseed showed a different pattern. Initially, the plants in the MIBA with fertilizer (RF) grew slower than the reference plants (Rref) (Figure 2b). However, after a few weeks, the rate increased and at harvest, the heights of the Rref and RF plants were almost the same. However, the height variation was larger for RF than for Rref, implying that cultivation in original MIBA is likely to be more diverse. Contrary to the sunflowers, the addition of fertilizer was crucial. After only a few weeks, the plants without nutrient addition (RwoF) already had a slower growth rate, and after 8 weeks, their growth stopped completely (Figure 2b). The leaves of these plants were purplish, which is a known effect of 
P deficiency; see, e.g., [40]. The $\mathrm{P}$ content was 5 times higher in MIBA than in soil, but was not in available forms for rapeseed (Table 1). Shortage of $P$ is more common in alkaline soils with low TOC and high Fe, and in plants with weak roots, which describes the conditions in the MIBA boxes without fertilizer (Tables 1 and 2). No difference in the growing capacity trends was observed for rapeseed plants planted at longer or shorter distances from each other, indicating that many plants can be cultivated in a limited space, giving a higher potential phytoextraction capacity.

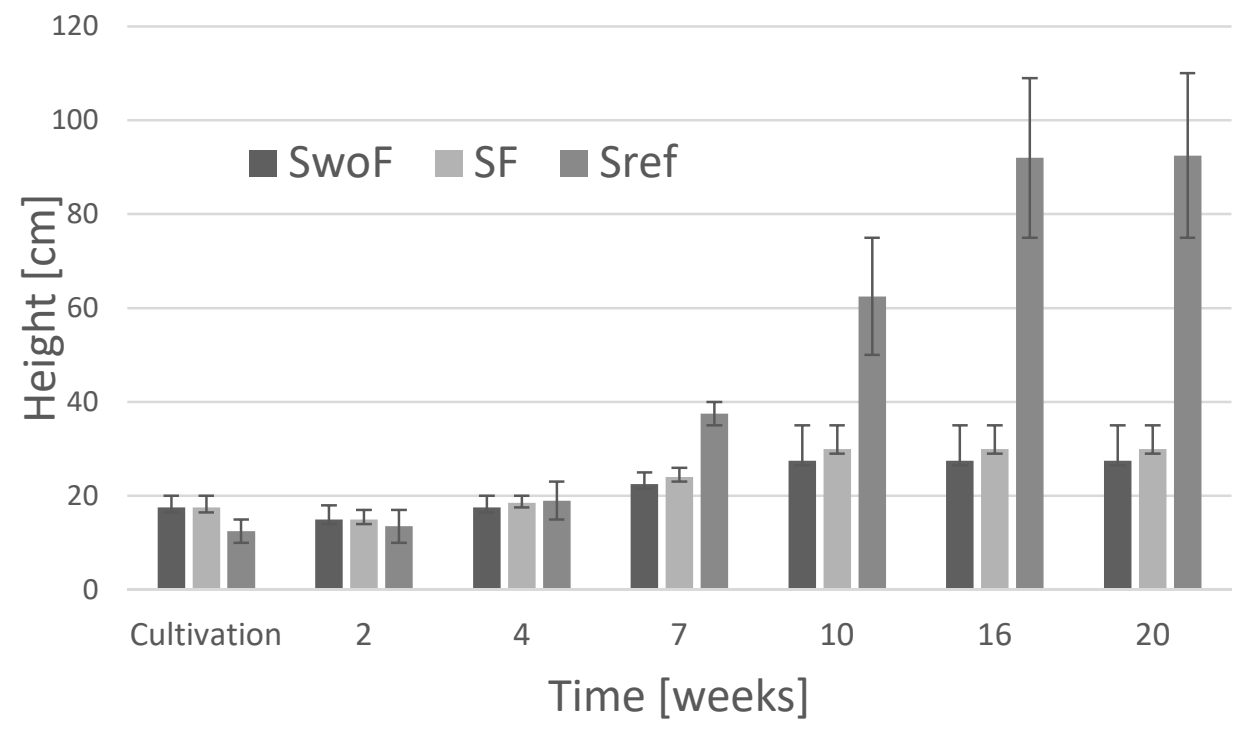

(a)

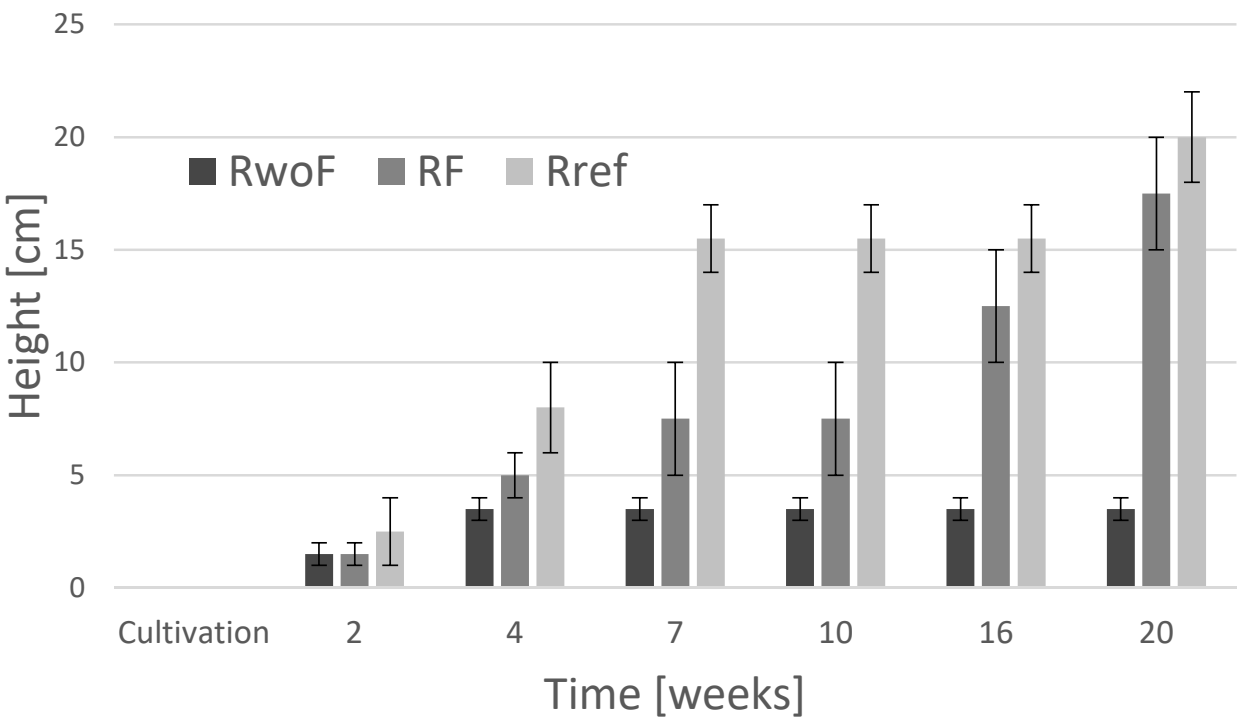

(b)

Figure 2. Average growth in $\mathrm{cm}$ for (a) sunflowers and (b) rapeseed cultivated in MIBA or reference soil (Sref and Rref) over 20 weeks. Error bars indicate variations in height.

The main fraction of the biomass was found in the above-ground biomass irrespective of the cultivation conditions or plant type (Table 2). However, the above-ground biomass was significantly higher for the control plants, Sref, than for the sunflowers grown in MIBA, which was due to the fact that the MIBA plants dried out and stopped growing. Both the heights and the distances between the plants in Rref and RF were similar, but the total biomass was approximately 3 times larger in the control plants, Rref (Figure $2 \mathrm{~b}$ and Table 2). The ocular inspection confirmed that both the above- and under-ground biomass of the RF 
plants was weaker than that of the Rref plants. This indicates that although the taproots of rapeseed developed better than those of the sunflowers, their growth was still restricted in MIBA. There are likely several reasons for this, and except for the higher bulk density of MIBA (Table 1), which can inhibit root growth [41], another major difference was the particle size distribution (Figure 3). MIBA contains a higher fraction of larger particles, which is well known to give lower water- and nutrient-holding capacities. At harvest, it was noted that the reference soil contained more water than the MIBA samples, despite the same amount of water having percolated through all cultivation boxes. This was also noted during the growing season, when the top layer of the MIBA appeared slightly drier than the reference soil. MIBA is known to be a draining material, and much of the added water probably percolated faster through the cultivation boxes and collected in the lower parts, where the roots were unable to reach it, while the water in the reference boxes was more evenly distributed. Additionally, the organic matter (TOC) in MIBA was low (Table 1), which further affects this. Mixing the MIBA with organic matter would likely give a better material for cultivation, as the presence of organic matter not only improves the nutrientand water-holding capacities but also provides better access to nutrients [42]. The fraction of smaller particles will increase, and organic matter can also protect plants from absorbing too much salt [42]. The latter might be of high importance in MIBA (Table 1).

Table 2. Above- and under-ground biomass yield [g] for sunflowers and rapeseed cultivated in MIBA or reference soil (Sref and Rref) with SD in brackets.

\begin{tabular}{ccc}
\hline Plant & Biomass Above-Ground/Plant & Biomass Under-Ground/Plant \\
\hline SwoF & {$[\mathrm{g}]$} & {$[\mathrm{g}]$} \\
SF & $0.8(0.1)$ & $0.2(0.04)$ \\
Sref & $0.8(<0.01)$ & $0.3(<0.01)$ \\
RwoF & $118(41)$ & $4.0(0.3)$ \\
RF & $0.1^{1}(0.01)$ & - \\
Rref & $0.2(0.02)$ & $0.1(<0.01)$ \\
\hline
\end{tabular}

${ }^{1}$ This includes the whole plant, due to insufficient biomass for division into parts.

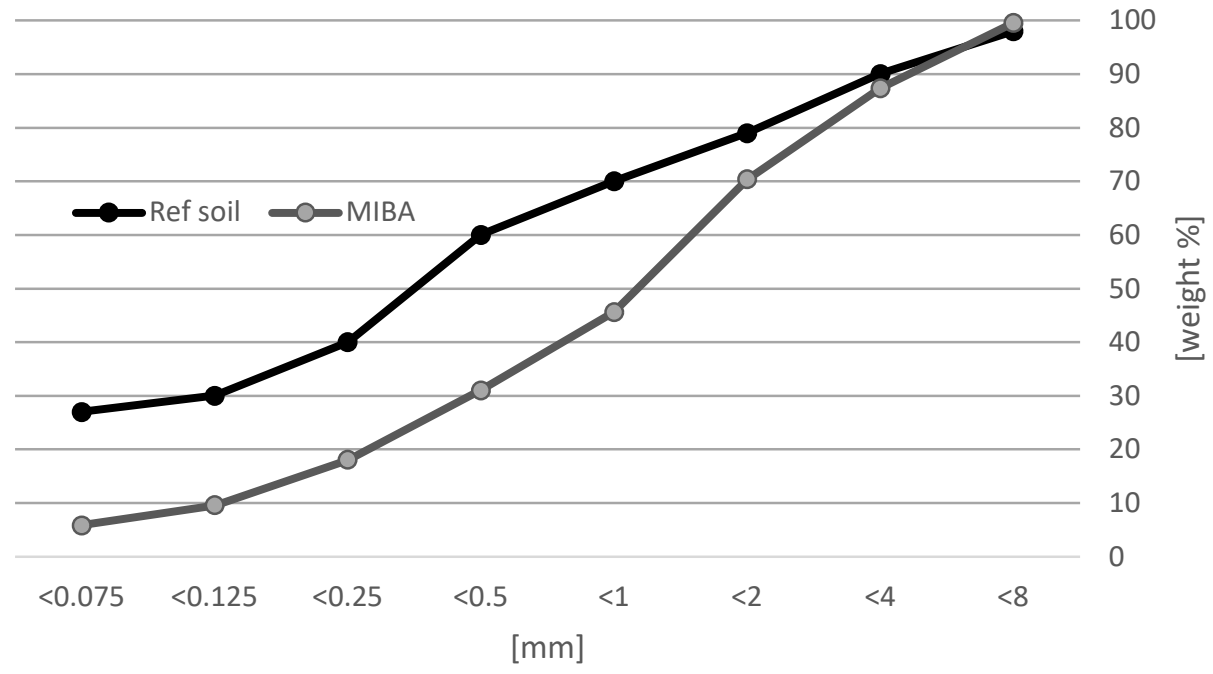

Figure 3. Cumulative particle size distribution curves for original reference soil and MIBA.

Rosenkranz et al. added compost in their study, but unfortunately, they did not include any cultivation in reference soil [25]. The mass above ground per rapeseed plant (Brassica $n$.) in their study was, however, consistent with the Rref in this study, showing the effect of the addition of organic matter to MIBA. However, the higher contents of especially $\mathrm{Cu}, \mathrm{Pb}$, and $\mathrm{Zn}$ in the conventional MIBA used here are also likely to have contributed to the inferior growth rate [37]. Cultivation of rapeseed in sandy soil contaminated with 
$\mathrm{Zn}$ and $\mathrm{Pb}$ in amounts corresponding to those in the MIBA used here resulted in $30 \%$ less above-ground biomass, indicating that the contamination level and the density of the cultivation material both have an impact [43].

\subsection{Metal Accumulation in Plants}

Although most of the biomass was present in the parts above ground, the highest metal concentrations were generally found in the roots for both plant types (Table 3). This was particularly true for minor and trace elements such as $\mathrm{Cu}, \mathrm{Pb}$, and $\mathrm{Zn}$ in $\mathrm{RF}$ (Table 3). Accumulation of $\mathrm{Pb}$ and $\mathrm{Zn}$ in rapeseed roots has previously been reported and suggested to be caused by the formation of low mobility compounds between the heavy metals and organic substances, as the metals enter the plasma in the roots $[29,43]$. For RwoF, the distribution could not be evaluated due to insufficient biomass. The distribution trend was weaker for the sunflowers, likely due to the limited germination of the MIBA plants. Earlier research has indicated that the $\mathrm{Zn}$ content is highest in the leaves of the sunflower [18]. However, this was not found in the present study, neither in the sunflowers planted in MIBA nor in those planted in the reference soil (Table 3). The metal contents were generally higher in the rapeseed plants grown in MIBA than in the sunflowers (Table 3). For instance, the $\mathrm{Zn}$ content in the below-ground biomass was about 10 times higher for the rapeseed plants than for the sunflowers (Table 3). This is probably because the root systems of rapeseed are more suitable for cultivation in MIBA than those of sunflowers, as discussed above, although the effects of potential water and nutrient shortages are also likely to influence this.

When calculating the bioaccumulation coefficients (BAC), i.e., the concentration of metal in plant parts above ground divided by the metal concentration in original MIBA, it is obvious that none of the used plant types should be classified as hyperaccumulators for any of the elements studied, as BAC $<1$. On the other hand, BAC might not be optimal for evaluating the extraction efficiency in this material, as MIBA is more complex and generally contains higher concentrations of metals than polluted soils. However, the results indicate that for most elements, the higher the pollutant content in the solid material, the higher the content in the plants. The $\mathrm{Zn}$ concentration was approximately 5 times higher in the above-ground sunflower parts cultivated in MIBA than in the reference soil, even though the growth was limited (Table 3). This was even more distinct for rapeseed, where the $\mathrm{Zn}$ concentrations detected in the RwF roots were almost 20 times higher than those in the Rref roots (Table 3 ). The highest enrichments compared to the reference cultivation were found for $\mathrm{Cu}$ (50 times), and for $\mathrm{Sn}$ and $\mathrm{Pb}$ (25 times). Marchiol et al. reported that the $\mathrm{Zn}$ content in rapeseed tissues cultivated in polluted soil substrate was 100 times higher than in reference soil, while the enrichment for elements like $\mathrm{Cu}$ and $\mathrm{Pb}$ was one order of magnitude higher [43]. This indicates that if the cultivation properties of MIBA are improved by, e.g., the addition of organic matter [42], the extraction efficiency in rapeseed probably will increase.

\subsection{Metal Contents in MIBA after Harvest}

Although the enrichment of several elements in the plants was significant, the observed decreases in the MIBA samples were limited (Figure 4). This was also confirmed by the low BACs, as calculated above. Except for elements that to a large extent form water-soluble compounds ( $\mathrm{Ca}, \mathrm{K}, \mathrm{Na}$, and S), i.e., are washed out during watering, no noteworthy changes in the MIBA composition were identified. Naturally, this was partly due to the limited growth, and better cultivation conditions would most likely result in higher extraction rates. Regardless, cultivation in MIBA should primarily be seen as a way to recover unutilized metals, rather than as a way to efficiently remediate the material, as this would take many years due to the complex contamination situation [22]. However, phytoextraction would likely decrease metal mobility, consequently enabling further utilization alternatives, even though metal compounds would still be present. 


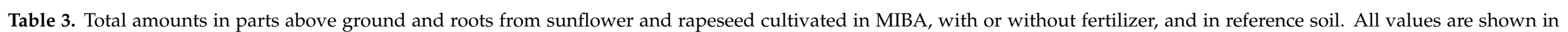
$\mathrm{mg} / \mathrm{kg}$ DS.

\begin{tabular}{|c|c|c|c|c|c|c|c|c|c|c|c|c|c|c|c|c|c|c|c|c|c|c|}
\hline \multirow[b]{3}{*}{ Element } & \multicolumn{12}{|c|}{ Sunflower } & \multicolumn{10}{|c|}{ Rapeseed } \\
\hline & \multicolumn{5}{|c|}{ Above Ground } & \multirow[b]{2}{*}{ sd } & \multicolumn{6}{|c|}{ Root } & \multicolumn{6}{|c|}{ Above Ground } & \multicolumn{4}{|c|}{ Root } \\
\hline & SwoF & sd & SF & sd & Sref & & SwoF & sd & SF & sd & Sref & sd & RwoF $^{1}$ & sd & RF & sd & Rref & sd & RF & sd & Rref & sd \\
\hline & \multicolumn{6}{|c|}{ [mg/kg DS] } & \multicolumn{6}{|c|}{ [mg/kg DS] } & \multicolumn{6}{|c|}{ [mg/kg DS] } & \multicolumn{4}{|c|}{ [mg/kg DS] } \\
\hline $\mathrm{Al}$ & 450 & 46 & 370 & 41 & 46 & 13 & 2600 & 1000 & 1000 & 170 & 5600 & 640 & 5200 & - & 270 & 150 & 210 & 77 & 9100 & 580 & 3500 & 2300 \\
\hline As & 0.22 & $<0.01$ & 0.35 & 0.04 & 0.09 & 0.06 & 1.8 & 1.2 & 0.88 & 0.13 & 1.8 & 0.25 & 4.4 & - & 0.32 & 0.06 & 0.16 & 0.05 & 8.4 & 0.12 & 0.99 & 0.63 \\
\hline $\mathrm{Ba}$ & 16 & 2.7 & 10 & 1 & 2.5 & 0.67 & 76 & 54 & 33 & 2.6 & 55 & 8.2 & 190 & - & 11 & 2.8 & 12 & 0.1 & 330 & 42 & 39 & 23 \\
\hline $\mathrm{Ca}$ & 14,000 & 3200 & 21,000 & 3100 & 5100 & 1000 & 15,000 & 8300 & 9000 & 180 & 7400 & 10 & 39,000 & - & 30,000 & 300 & 22,000 & 300 & 61,000 & 2100 & 5100 & 1000 \\
\hline $\mathrm{Cd}$ & 0.05 & $<0.01$ & 0.07 & $<0.01$ & 0.01 & $<0.01$ & 0.35 & 0.16 & 0.21 & 0.04 & 0.16 & $<0.01$ & 0.82 & - & 0.09 & $<0.01$ & 0.04 & $<0.01$ & 1.3 & 0.07 & 0.08 & 0.04 \\
\hline $\mathrm{Co}$ & 0.35 & 0.01 & 0.46 & 0.08 & 0.04 & 0.01 & 2.1 & 1.5 & 1.2 & 0.1 & 3.5 & 0.68 & 6.8 & - & 0.59 & 0.17 & 0.41 & 0.03 & 10 & 0.25 & 2.3 & 1.7 \\
\hline $\mathrm{Cr}$ & 1.5 & 0.26 & 1.2 & 0.16 & 0.15 & 0.02 & 9.6 & 6.7 & 4.1 & 0.42 & 7.3 & 0.97 & 19 & - & 1.2 & 0.43 & 1.2 & 0.73 & 65 & 31 & 4.7 & 3.1 \\
\hline $\mathrm{Cu}$ & 12 & 0.35 & 16 & 1.9 & 8 & 0.97 & 180 & 120 & 110 & 30 & 36 & 7.9 & 430 & - & 39 & 7.9 & 10 & 4.8 & 570 & 19 & 11 & 6.1 \\
\hline $\mathrm{Fe}$ & 730 & 75 & 630 & 110 & 80 & 33 & 2100 & 1600 & 770 & 170 & 7900 & 1400 & 5200 & - & 200 & 77 & 260 & 72 & 7600 & 920 & 4700 & 3400 \\
\hline $\mathrm{Hg}$ & 0.02 & $<0.01$ & 0.02 & $<0.01$ & $<0.01$ & $<0.01$ & $<0.01$ & $<0.01$ & $<0.01$ & $<0.01$ & 0.05 & $<0.01$ & 0.01 & - & $<0.01$ & $<0.01$ & 0.02 & $<0.01$ & 0.02 & $<0.01$ & $<0.02$ & $<0.02$ \\
\hline K & 4400 & 400 & 4100 & 790 & 13,000 & 2700 & 21,000 & 6400 & 17,000 & 4600 & 16,000 & 3800 & 16,000 & - & 30,000 & 2500 & 29,000 & 1500 & 12,000 & 100 & 11,000 & 990 \\
\hline $\mathrm{Mg}$ & 1400 & 15 & 1600 & 45 & 940 & 44 & 2200 & 360 & 1200 & 55 & 2800 & 330 & 3000 & - & 2800 & 5 & 2900 & 130 & 2900 & 130 & 2400 & 960 \\
\hline $\mathrm{Mn}$ & 27 & 3.6 & 43 & 4.8 & 8.8 & 1 & 64 & 46 & 34 & 3.1 & 190 & 35 & 200 & - & 52 & 3.9 & 24 & 3 & 300 & 2 & 120 & 79 \\
\hline Mo & 0.78 & 0.06 & 1.3 & 0.03 & 0.15 & 0.06 & 5.1 & 2.6 & 5.2 & 0.9 & 2.2 & 0.6 & 8.1 & - & 3.9 & 0.18 & 11 & 1.6 & 9.5 & 0.16 & 1.7 & 0.23 \\
\hline $\mathrm{Ni}$ & 1.2 & 0.08 & 1.3 & 0.11 & 0.19 & 0.05 & 13 & 11 & 5 & 0.39 & 5.2 & 0.9 & 31 & - & 3.7 & 0.73 & 2.3 & 0.19 & 52 & 5 & 4.8 & 1.8 \\
\hline $\mathrm{P}$ & 530 & 7.5 & 650 & 72 & 2300 & 270 & 480 & 230 & 340 & 2.5 & 2400 & 470 & 2600 & - & 3000 & 190 & 3400 & 290 & 3700 & 440 & 3000 & 720 \\
\hline $\mathrm{Pb}$ & 3 & 0.02 & 2.6 & 0.24 & 0.23 & 0.03 & 37 & 27 & 18 & 2 & 11 & 1.5 & 91 & - & 3.6 & 1.4 & 1.1 & 0.53 & 170 & 11 & 6.6 & 4.1 \\
\hline$S$ & 1200 & 45 & 2500 & 60 & 820 & 40 & 4000 & 65 & 3700 & 890 & 1400 & 110 & 9300 & - & 13,000 & 50 & 7500 & 190 & 6700 & 310 & 2100 & 55 \\
\hline Se & $<0.01$ & $<0.01$ & $<0.01$ & $<0.01$ & $<0.05$ & $<0.01$ & $<0.08$ & $<0.03$ & $<0.05$ & $<0.01$ & 0.22 & 0.03 & 0.32 & - & 0.17 & 0.01 & $<0.09$ & $<0.04$ & 0.36 & 0.02 & $<0.12$ & $<0.07$ \\
\hline Sn & 0.52 & 0.02 & 0.3 & 0.02 & $<0.02$ & $<0.01$ & 4.8 & 3.8 & 1.9 & 0.45 & 0.27 & 0.03 & 4 & - & 0.4 & 0.14 & 0.09 & 0.02 & 7.5 & 0.65 & 0.15 & 0.06 \\
\hline $\mathrm{V}$ & 1.3 & 0.18 & 1.1 & 0.22 & 0.13 & 0.06 & 2.8 & 2.1 & 1.2 & 0.05 & 18 & 0.75 & 5.6 & - & 0.25 & 0.09 & 0.45 & 0.1 & 9 & 0.27 & 9.8 & 6.7 \\
\hline $\mathrm{Zn}$ & 59 & 1.2 & 88 & 7.5 & 16 & 0.35 & 460 & 28 & 110 & 18 & 88 & 8.2 & 700 & - & 100 & 1.7 & 38 & 8.9 & 1000 & 10 & 56 & 26 \\
\hline
\end{tabular}

${ }^{1}$ Whole plant due to limited biomass. 


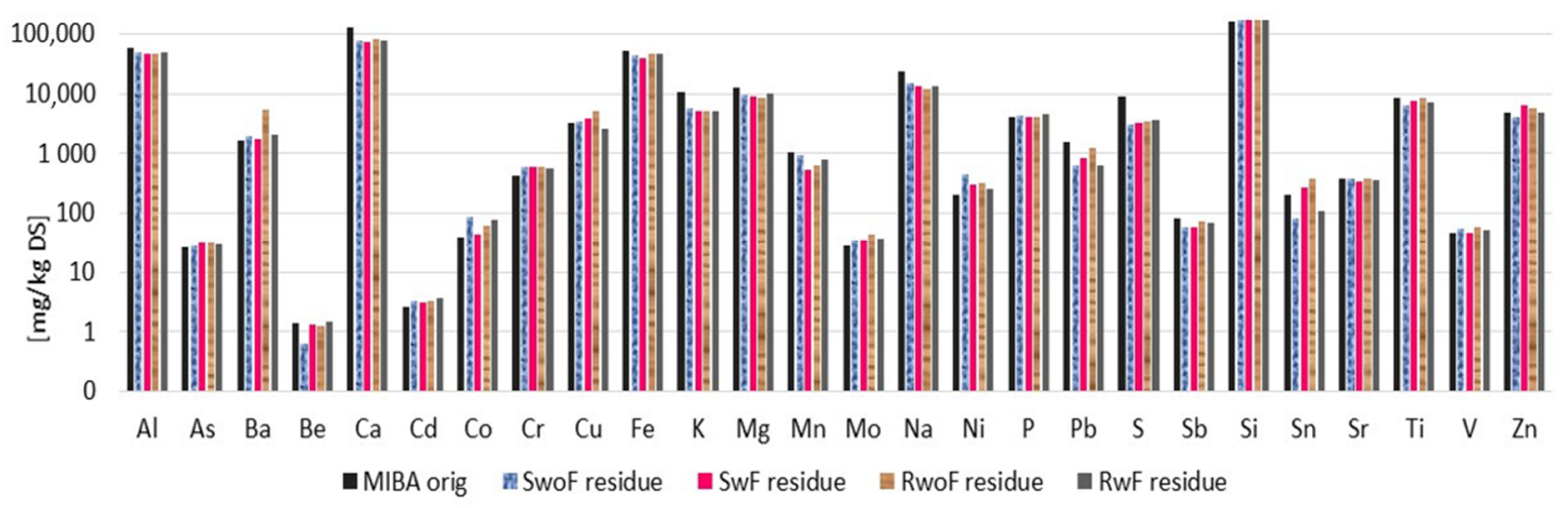

Figure 4. Contents (mg/kg DS) of selected elements in MIBA before and after cultivation of sunflowers and rapeseed.

\subsection{Potential for Recovery of $\mathrm{Zn}$ and Other Metals from MIBA}

From the results, it is obvious that the direct cultivation of sunflowers and rapeseed in conventional MIBA is not straightforward. However, although both growth and metal reduction were limited, a glimpse of the potential for using plants grown in MIBA as a metal-enriched biofuel is shown. Plants from phytoextraction could be incinerated in WtE plants, and the metals could be recovered from the fly ash, as discussed in the Introduction. Calculations assuming $6 \%$ of fly ash mass after incineration of rapeseed plants [44] provide ash with interesting quantities of $\mathrm{Co}, \mathrm{Cu}, \mathrm{Pb}$, and $\mathrm{Zn}$, for which the estimated amounts are comparable to workable ores (Table 4) [45]. Additionally, Co has been identified by the EC as a critical raw material [1]. However, for this to be interesting on a larger scale, metal enrichment in these plants must increase. In addition to improving important cultivation parameters of MIBA, such as the particle size distribution and the content of organic matter, the choice of more suitable plants for phytoextraction in this kind of material is urgent. As the metal content in MIBA is high, it would probably be more efficient to use perennial plants, as one cultivation season is too short to reach efficient extraction. For instance, plants in the salix family could be an alternative, as they are known to grow in highly polluted soils in the climate of northern Europe and have a high capacity for extracting $\mathrm{Zn}$ and other metals [20-22]. In a study using Salix caprea, Zn was enriched in the leaves, while $\mathrm{Co}, \mathrm{Cu}$, and $\mathrm{Ni}$ had mainly accumulated in the roots [20]. By collecting the leaves regularly, Zn can be recovered continuously, whereas metals mainly enriched in the roots can only be recovered when the whole plant is harvested. An additional advantage with plants in the salix family is their high biomass; this makes them suitable for incineration, which makes them interesting from an energy perspective as well, as they may be capable of displacing fossil fuels.

Table 4. Calculated indicative contents of $\mathrm{Co}, \mathrm{Cu}, \mathrm{Pb}$, and $\mathrm{Zn}$ in ash after incineration of $\mathrm{RF}$ plants. For comparison, contents in workable ores are shown [45]. All amounts are given in \%.

\begin{tabular}{cccc}
\hline Element & Whole Plant Ash & Root Ash & Workable Ore \\
\hline & {$[\%]$} & {$[\%]$} & {$[\%]$} \\
\hline $\mathrm{Co}$ & 0.007 & 0.02 & $0.01-0.08$ \\
$\mathrm{Cu}$ & 0.42 & 0.95 & $0.14-2.6$ \\
$\mathrm{~Pb}$ & 0.12 & 0.29 & $0.30-9.4$ \\
$\mathrm{Zn}$ & 0.78 & 1.7 & $0.31-12$ \\
\hline
\end{tabular}

\section{Conclusions}

This paper discusses for the first time, to the knowledge of the authors, the potential of cultivating annual plants in conventional MIBA in order to generate metal-enriched biomass fuel, which is to be used for metal recovery. 
The results show that cultivation of rapeseed and sunflowers in conventional MIBA is challenging. The main explanations for this are the inhibited root development and low water- and nutrient-holding capacities caused by unsuitable properties such as the high fraction of large particles, the low TOC content, and the high density of MIBA. Rapeseed plants with more developed taproots grew better than sunflowers, but the addition of fertilizer was crucial.

There was an accumulation of numerous metals in both plant types, and the highest metal content was generally found in the roots. Calculations indicated ash from rapeseed root incineration contained $2 \% \mathrm{Zn}$, and the contents of $\mathrm{Co}, \mathrm{Cu}$, and $\mathrm{Pb}$ were comparable to those in workable ores. The metal reduction in MIBA after cultivation was limited.

The results indicate that to promote phytoextraction on MIBA, the material itself should be refined, but also the choice of plants is important. Perennials with roots that efficiently penetrate the compact MIBA material, e.g., members of the salix family, are theoretically suitable. This initial study shows that cultivation in and phytoextraction on MIBA is possible, but further research is needed.

Author Contributions: Conceptualization, K.K.F., V.E. and D.D.; Investigation, K.K.F.; Methodology, K.K.F., V.E. and D.D.; Resources, K.K.F., V.E. and D.D.; Visualization, K.K.F.; Writing-original draft, K.K.F. All authors have read and agreed to the published version of the manuscript.

Funding: This research was funded by "the Ash program", managed by Energiforsk (2018-113) and Avfall Sverige (F226), grant number (2018-113) and (F226).

Institutional Review Board Statement: Not applicable.

Informed Consent Statement: Not applicable.

Acknowledgments: This work was supported by the "Ash program", managed by Energiforsk (2018-113) and Avfall Sverige (F226), which is gratefully acknowledged. Sandra Dassoum is recognized for her assistance with cultivation management.

Conflicts of Interest: The authors declare no conflict of interest.

\section{References}

1. European Commission. Report on the Critical Raw Materials for the EU, Report of the Ad Hoc Working Group on Defining Critical Raw Materials; European Commission: Brussels, Belgium, 2014; p. 41.

2. Avfall Sverige. Svensk Avfallshantering 2018; Avfall Sverige: Malmö, Sweden, 2019.

3. Blasenbauer, D.; Huber, F.; Lederer, J.; Quina, M.; Blanc-Biscarat, D.; Bogush, A.; Bontempi, E.; Blondeau, J.; Chimenos, J.M.; Dahlbo, H.; et al. Legal situation and current practice of waste incineration bottom ash utilisation in Europe. Waste Manag. 2020, 102, 868-883. [CrossRef] [PubMed]

4. Arickx, S.; Van Gerven, T.; Vandecasteele, C. Accelerated carbonation for treatment of MSWI bottom ash. J. Hazard. Mater. 2006, 137, 235-243. [CrossRef]

5. Freyssinet, P.; Piantone, P.; Azaroual, M.; Itard, Y.; Clozel-Leloup, B.; Guyonnet, D.; Baubron, J. Chemical changes and leachate mass balance of municipal solid waste bottom ash submitted to weathering. Waste Manag. 2002, 22, 159-172. [CrossRef]

6. Klymko, T.; Dijkstra, J.J.; Van Zomeren, A. Guidance Document on Hazard Classification of MSWI Bottom Ash in ECN-E-17-024; Confederation of European Waste-to-Energy Plants: Düsseldorf, Germany, 2017.

7. Tiberg, C.; Sjöstedt, C.; Fedje, K.K. Speciation of copper and zinc in MSWI bottom ash studied by XAS and geochemical modelling. Waste Manag. 2021, 119, 389-398. [CrossRef] [PubMed]

8. Fedje, K.K.; Strömvall, A.-M. Enhanced soil washing with copper recovery using chemical precipitation. J. Environ. Manag. 2019, 236, 68-74. [CrossRef]

9. Barbaroux, R.; Plasari, E.; Mercier, G.; Simonnot, M.-O.; Morel, J.L.; Blais, J. A new process for nickel ammonium disulfate production from ash of the hyperaccumulating plant Alyssum murale. Sci. Total Environ. 2012, 423, 111-119. [CrossRef]

10. Delplanque, M.; Collet, S.; Del Gratta, F.; Schnuriger, B.; Gaucher, R.; Robinson, B.; Bert, V. Combustion of Salix used for phytoextraction: The fate of metals and viability of the processes. Biomass-Bioenergy 2013, 49, 160-170. [CrossRef]

11. Rasmusen, E. Sambehandling Af RGA Og Scrubber Væske Fra Forbrændingsanlæg Med HALOSEP Processen, Miljøprojekt Nr. 1648; Danish EPA: Copenhagen, Denmark, 2015.

12. Schlumberger, S.; Bühler, J. Metal Recovery in Fly and Filter Ash in Waste to Energy Plants. In Ash 2012; Strömberg, B., Ed.; Värmeforsk AB: Stockholm, Sweden, 2012.

13. Fedje, K.K.; Andersson, S. Zinc recovery from Waste-to-Energy fly ash-A pilot test study. Waste Manag. 2020, 118, 90-98. [CrossRef] 
14. Odjegba, V.J.; Fasidi, I.O. Phytoremediation of heavy metals by Eichhornia crassipes. Environmentalist 2007, 27, 349-355. [CrossRef]

15. Zhao, L.; Yuan, L.; Wang, Z.; Lei, T.; Yin, X. Phytoremediation of zinc-contaminated soil and zinc-biofortification for human nutrition. In Phytoremediation and Biofortification; Yin, X., Yuan, L., Eds.; Springer Briefs in Molecular Science: Dordrecht, The Netherlands, 2012; pp. 33-57.

16. Wrobel, S. Sunflower yields as an indicator of zinc polluted soil detoxification. Fresenius Environ. Bull. 2010, 19, 330-334.

17. Belouchrani, A.S.; Mameri, N.; Abdi, N.; Grib, H.; Lounici, H.; Drouiche, N. Phytoremediation of soil contaminated with Zn using Canola (Brassica napus L). Ecol. Eng. 2016, 95, 43-49. [CrossRef]

18. Adesodun, J.K.; Atayese, M.O.; Agbaje, T.A.; Osadiaye, B.A.; Mafe, O.F.; Soretire, A. Phytoremediation Potentials of Sunflowers (Tithonia diversifolia and Helianthus annuus) for Metals in Soils Contaminated with Zinc and Lead Nitrates. Water Air Soil Pollut. 2009, 207, 195-201. [CrossRef]

19. Fulekar, M.H. Phytoremediation of Heavy Metals by Helianthus annuus in Aquatic and Soil environment. Int. J. Curr. Microbiol. Appl. Sci. 2016, 5, 392-404. [CrossRef]

20. Varga, C.; Marian, M.; Mihaly-Cozmuta, L.; Mihaly-Cozmuta, A.; Mihalescu, L. Evaluation of the phytoremediation potential of the Salix caprea in tailing ponds. An. Univ. Oradea Fasc. Biol. 2009, 16, 141.

21. Hauptvogl, M.; Kotrla, M.; Prčík, M.; Žaneta, P.; Kováčik, M.; Lošák, T. Phytoremediation Potential of Fast-Growing Energy Plants: Challenges and Perspectives-A Review. Pol. J. Environ. Stud. 2019, 29, 505-516. [CrossRef]

22. Pulford, I.D.; Watson, C. Phytoremediation of heavy metal-contaminated land by trees-A review. Environ. Int. 2003, 29, 529-540. [CrossRef]

23. Bilski, J.; Jacob, D.; McLean, K.; McLean, E.; Soumaila, F.; Lander, M. Agro-toxicological aspects of coal fly ash (FA) phytoremediation by cereal crops: Effects on plant germination, growth and trace elements accumulation. Adv. Biores. 2012, 3, 121-129. [PubMed]

24. Krgovic, R.; Trifković, J.; Milojković-Opsenica, D.; Manojlovic, D.; Markovic, M.; Mutić, J. Phytoextraction of metals by Erigeron canadensis L. from fly ash landfill of power plant "Kolubara". Environ. Sci. Pollut. Res. 2015, 22, 10506-10515. [CrossRef]

25. Rosenkranz, T.; Kisser, J.; Wenzel, W.W.; Puschenreiter, M. Waste or substrate for metal hyperaccumulating plants-The potential of phytomining on waste incineration bottom ash. Sci. Total Environ. 2017, 575, 910-918. [CrossRef]

26. Renova, A.B. Jordprodukter. 2019. Available online: https://www.renova.se/foretag/produkter-och-tjanster/jordprodukter/ (accessed on 10 December 2019).

27. Granngården, A.B. Promagna 11-5-18. 2019. Available online: https://www.granngarden.se/godsel-promagna-11-5-18-25-kg/ $\mathrm{p} / 1196440$ (accessed on 10 December 2019).

28. Kassas, H.; Sharaf, M.; Abdou, M.M.N. Phytoremediation of zinc and copper. J. Eniviron. Sci. 2003, 7, 323.

29. Angelova, V. Potential of rapeseed (Brassica napus L.) for phytoremediation of soils contaminated with heavy metals. J. Environ. Prot. Ecol. 2017, 18, 468-478.

30. Arm, M. Handbook—Bottom Ash in Road and Public Construction (In Swedish; Handbok—Slaggrus I Väg-Och Anläggning-Sarbeten); Institue, S.G., Ed.; Swedish Geotechnical Institute: Linköping, Sweden, 2006.

31. Serti, S.; Löfgren, M. Guidance for Classification of Incinceration Residues Using Calculation 2018:13 (In Swedish; Vägledning for Klassificering Av Förbränningsrester Med Beräkningsmetoder); Management, S.A.o.W., Ed.; Swedish Association of Waste Management: Malmö, Sweden, 2018.

32. Tessier, A.; Campbell, P.; Bisson, M. Sequential extraction procedure for the speciation of particulate trace metals. Anal. Chem. 1979, 51, 844-851. [CrossRef]

33. ALS Scandinavia AB. Sequential Extraction, version 20-01-2018; ALS Scandinavia AB: Luleå, Sweden, 2018 (In Swedish). Available online: www.alsglobal.se (accessed on 20 January 2018).

34. Ozolinčius, R.; Varnagirytė-Kabašinskienė, I.; Stakènas, V.; Mikšys, V. Effects of wood ash and nitrogen fertilization on Scots pine crown biomass. Biomass-Bioenergy 2007, 31, 700-709. [CrossRef]

35. Zhang, Z.; He, F.; Zhang, Y.; Yu, R.; Li, Y.; Zheng, Z.; Gao, Z. Experiments and modelling of potassium release behavior from tablet biomass ash for better recycling of ash as eco-friendly fertilizer. J. Clean. Prod. 2018, 170, 379-387. [CrossRef]

36. Drott, A.; Anderson, S.; Eriksson, H. Rules and Recommendations for Forest Fuel Extraction and Compensation Action, Report 2019/14 (In Swedish: Regler Och Rekommendationer för Skogsbränsleuttag Och Kompensationsåtgärder, Rapport 2019/14); Skogsstyrelsen, S.F.A., Ed.; Swedish Forest Agency: Jönköping, Sweden, 2019.

37. Wong, M.H.; Bradshaw, A.D. A comparison of the toxicity of heavy metals, using root elongation of rye grass, lolium perenne. New Phytol. 1982, 91, 255-261. [CrossRef]

38. Oosterbaan, R.J. Cropo tolerance to soil salinity, statistical analysis of data measured in farm lands. Int. J. Agric. Sci. 2018, 3, 57-66.

39. Küpper, H.; Zhao, F.-J.; McGrath, S.P. Cellular Compartmentation of Zinc in Leaves of the Hyperaccumulator Thlaspi caerulescens. Plant Physiol. 1999, 119, 305-312. [CrossRef]

40. Yara, U.K. Phosphorus Deficiency-Oilseed Rape. 2020. Available online: https://www.yara.co.uk/crop-nutrition/oilseed-rape/ nutrient-deficiencies-oilseed-rape/phosphorus-deficiency-oilseed-rape/ (accessed on 7 April 2020).

41. Magdoff, F.; van Es, H. Building Soils for Better Crops Sustainable Soil Management, 3rd ed.; Handbook Series Book 10th ed.; Sustainable Agriculture Research and Education (SARE) and USDA's National Institute of Food and Agriculture, University of Maryland and University of Vermont: Brentwood, CA, USA, 2019. 
42. Bot, A.; Benites, J. The Importance of Soil Organic Matter Key to Drought-Resistant Soil and Sustained Food Production; Food and Agriculture Organization of the United Nations: Rome, Italy, 2005.

43. Marchiol, L.; Assolari, S.; Sacco, P.; Zerbi, G. Phytoextraction of heavy metals by canola (Brassica napus) and radish (Raphanus sativus) grown on multicontaminated soil. Environ. Pollut. 2004, 132, 21-27. [CrossRef]

44. Strömberg, B.; Svärd, S.H. Handbook for Fuel A08-819 (In Swedish: Bränslehandboken A08-819); Strömberg, B., Ed.; Värmeforsk: Stockholm, Sweden, 2012.

45. Fennoscandian Mineral Deposits Application. Ore Deposits Database and Maps; Geological Survey of Finland: Espoo, Finland, 2020. 